Cite as: Pollack, J., Algeo, C. (2014) Perspectives on formal authority between Project Managers and Change Managers. Project Management Journal, 45(5), 27-43, DOI: 10.1002/pmj.21446.

\title{
Perspectives on the Formal Authority between Project Managers and Change Managers
}

\author{
Julien Pollack, Chivonne Algeo \\ University of Technology, Sydney
}

\begin{abstract}
Project management and change management both contribute to the management and delivery of changes to organizations; however, they are based on distinct bodies of knowledge, and practitioners of these disciplines have disparate views on how change should be managed. There is a lack of consensus about how these disciplines should work together to deliver organizational change projects which may result in conflict. This research delves into practitioners' perspectives on formal authority, the reporting relationship between these disciplines, and reveals the fundamental differences in how practitioners of these disciplines view the practice of organizational change.
\end{abstract}

Keywords: project management; change management; reporting; formal authority; organizational change

\section{Introduction}

Project management and change management are two disciplines that have the potential to jointly make a contribution to the delivery of change initiatives in organizations, and examples can be found in the normative and academic project management literature (Project Management Institute, 2013a; Winch, Muenier, Head, \& Russ, 2012; Boddy \& Macbeth, 2000), change management literature (Change Management Institute, 2012; Griffith-Cooper \& King, 2007; Leppitt, 2006; Leybourne, 2006), and the general management literature (Levasseur, 2010; Pádár, Pataki, \& Sebestyen, 2011) to support this assertion.

Evidence in the literature suggests, however, a lack of consensus and even conflict regarding how these disciplines should work together to deliver organizational change projects (Crawford \& Nahmais, 2010, p. 405; Jarocki, 2011, p. 69). This may partly be attributed to the different traditions, contextual backgrounds, and bodies of knowledge associated with these disciplines (Lehmann, 2010, pp 331-332; Garfein \& Sankaran, 2011, p. 4). For example, the early development of project management has been influenced by the aerospace industry (Morris, 2013, p. 13), drawing on hard systems approaches, such as systems engineering, systems analysis (Morris, 2002), and cybernetics (Urli \& Urli, 2000, p. 33), and emphasizing the use of quantitative techniques to control budget, schedule, and the quality of a delivered product (Yeo, 1993, p. 115).

By way of contrast, change management is a comparatively younger field, drawing on a rich literature on strategy, organizational development, and human relations (Crawford \& Nahmais, 2010, p. 406), including work by Phillips (1983) and Connor (1993). There are many different approaches to change management (Mento, Jones, \& Dirndorfer, 2002) and readers are referred to Cao and McHugh (2005) for a comprehensive review of the development of the discipline. Although both disciplines focus on creating change in organizations, when compared with the more traditional literature on project management, change management focuses less on control of delivery through a direct means-end 
Cite as: Pollack, J., Algeo, C. (2014) Perspectives on formal authority between Project Managers and Change Managers. Project Management Journal, 45(5), 27-43, DOI: 10.1002/pmj.21446.

orientation than on communication of a clear vision for a future state, engaging leadership in the change process, ensuring alignment with strategy, and the development of ownership of a change by an organization. In addition, Lehmann (2010, p. 328) notes that a key difference between the disciplines is that, while change management has focused on the underlying dynamics of change, project management has tended to place a greater emphasis on method and technique. The different foci of these disciplines may be a source of conflict in the delivery of organizational change projects if practitioners hold contradictory views about how a change should be managed.

Although the literature on these disciplines may have once been clearly distinct, authors contributing to the project management literature appear to be increasingly drawing on, and writing about, issues more commonly associated with change management. For example, Leybourne (2007) has noted a move from project management research that focuses on process to research that focuses on people. Similarly, Kloppenborg and Opfer (2002) found an increasing trend toward people-related issues in project management research, such as teams, leadership, and motivation, whereas Urli and Urli (2000) found project managment research has increasingly extended itself toward organizational change. Project Management Institute's recent inclusion of a tenth Knowledge Area, Project Stakeholder Management, which focuses on stakeholder management in A Guide to the Project Management Body of Knowledge (PMBOK ${ }^{\circledR}$ Guide) (PMI, 2013b) can also be taken as evidence of a growing focus on people-related issues in the discipline. Conversely, Söderlund (2004) has identified that not only is project management research drawing on a broader range of sources, it is also being drawn upon by a wider range of sources, including the general management disciplines; a point supported by Kwak and Anbari (2009).

This suggests that, although much of the project management literature may remain focused on technical issues of quantitative control and top-down management, there may be a narrowing divide between the works of literature in those parts where the project management literature deals directly with the management of organizational change, or in other management contexts where a response to ambiguity or stakeholder engagement remains the key to success. It is interesting to note that in two comparative reviews of the literature, one focusing on stakeholder roles (Pádár et al., 2011), and one on communication (Lehmann, 2010), found similarities between the literatures, with the latter study finding that recent publications in these fields are increasingly convergent. Indeed, it has been identified that there is an "...obvious overlap between the two disciplines..." (Jarocki, 2011, p. 69) The line between the disciplines appears to be blurring, at least from the perspective of what researchers write about. Differences in the literature do not then appear to be the likely source of any significant disciplinary conflict.

Nonetheless, it has been found that "...there is evidence of a degree of rivalry between project managers and change managers concerning who should be managing business change" (Crawford \& Nahmais, 2010, p. 405). Given the increasing convergence in the literature, evidence of whether conflict between these disciplines exists may be less apparent in the literature than in the opinions of practitioners; this is where project managers and change managers are finding ways to work together to deliver organizational change projects. As such, this research primarily delves into the opinions of practitioners; first to uncover whether there are differences of opinion between practitioners of these disciplines; and second, to contribute to clarifying what the differences are, so that practitioners may be better able to manage any conflict resulting from these differences of opinion.

If the literature supporting these disciplines increasingly overlaps, then there is the possibility of further confusion amongst practitioners about how these disciplines should relate to each other. With both disciplines regarding themselves as experts in the delivery of organizational change projects, one key area of disagreement will likely relate to which discipline holds ownership over the process of organizational change, either in terms of 
Cite as: Pollack, J., Algeo, C. (2014) Perspectives on formal authority between Project Managers and Change Managers. Project Management Journal, 45(5), 27-43, DOI: 10.1002/pmj.21446.

specific parts of that change or authority over the process in its entirety. Both project management and change management claim to contribute to the delivery of organizational change, and yet there is little in the literature to suggest how these roles should relate in practice. In response, this paper addresses the following research question:

Do project managers and change managers hold different views about how these two roles should formally relate in practice?

\section{Alternative Relationships between the Disciplines}

As noted above, there is little in the research literature that discusses issues of formal positional authority and the reporting relationship between project managers and change managers ; however, review of the literature does reveal hints at various authors' perspectives on this topic, suggesting four possible ways in which the roles could interact:

1. Project managers should report to change managers;

2. Change managers should report to project managers;

3. There should be a joint partnership between the roles, with no direct reporting relationship; and

4. The roles are entirely distinct with no need for partnership, with no direct reporting relationship.

Support for the first of these four positions can be seen in Kotter (1996), arguably one of the most influential works on the change management methods, which refers to project management as being a component of the a change management process. When describing an approach to change management, he refers to "Project management and leadership from below: Lower ranks in the hierarchy both provide leadership for specific projects and manage those projects" (p. 143). Leppitt (2006, p. 238) could also be interpreted as implying that project management functions are at lower parts of an organization than change management functions.

Support for the view that project managers should report to change managers can also be found in the project management literature. Gareis $(2010$, p. 316$)$ has identified that the major program management standards depict program managers and change managers sitting at comparable levels. Cowan-Sahadath (2010) provides a complimentary view of this relationship, at one point describing project management as more relatable to operational performance and middle management, with change management as being alongside vision, strategy, and senior management (p. 399), and at another point depicting change ownership on the same level as program management, both of which are depicted as below leadership, but above the project teams (p. 400). In addition, Stummer and Zuchi (2010) wrote that the "...change manager is responsible for the overall change and is in charge of the transitions between the change processes. Where the responsibility of the program or project manager ends, the responsibility of the change manager begins." (2010, p. 391) One consistent theme is that those views from the project management literature that regard change management as being at a higher organizational level than project management is that they regard change management as being more equivalent to program management.

The view that project management is a lower level organizational activity than change management is far from consistent, and support for the second position is clearly evident in the literature. In many sources, where there is some implication about a reporting relationship, the literature appears to suggest that change managers should report to project managers. For example, when describing the relationship between project management and change management, Lehmann $(2010$, p. 331) states that a "...project is conducted by a project manager ... acting as a chief officer in command of a dedicated team"; this is similar to the view stated by Fiedler (2010, p. 377). It is also implied in some sources that change 
management is part of, or subservient to, project management. Cowan-Sahadath (2010) also describes the "...need for a proven, mature project management methodology that included effective communications, change management plans..." (p. 400), whereas Nelson (2011, p.6) states that "...there should be linking milestones and activities that are common in both the change management workplan and the master project workplan." Both of the preceding references suggest that change management activity is controlled to an overarching project management plan. Evidence is apparent in the works of other authors (e.g., Turner, Grude, \& Thurloway, 1996; Boddy \& Macbeth, 2000; Dover, 2002) implying that project managers are responsible for managing change issues, whereas Clarke (1999, p. 139) suggests that project management can be used by itself to manage change. Crawford and Nahmais (2010, p. 409) elaborate on this by suggesting that in any change project, other than those with a weak supportive culture and/or leadership and a high degree of required behavioral change, the change can be managed by a project manager with some change management skills, suggesting that in most cases change management is not needed or can be considered supplementary to project management.

A thorough reading of PMl's Managing Change in Organizations: A Practice Guide (2013a) complicates this discussion, as the guide does not acknowledge the role of the change manager, treating change management as an abstract group of skills, foci, and activities, rather than as capabilities embodied in a distinct group of specialists. The guide appears to consider change management to be more akin to portfolio and program management, because of their common interests in strategic alignment, benefits management, and distributed control, but does allow fo change management activities at the project level. With respect to the relationship between project management and change management, the guide refers to change management activities being undertaken by portfolio, program, or project managers, which could be interpreted as suggesting that the role of the change manager is superfluous.

There is also evidence of support for the third position of joint and equal responsibility for success, with the implication for no need for any direct reporting relation between project and change managers. Alsene (1998) has identified three case studies in which change agents held personal responsibility for project success, alongside the project manager. The Change Management Institute (CMI) also identifies the need for a change manager to understand "...the roles and relationships of the project manager, project team and other stakeholders and is able to competently manage those relationships" (2008, p. 4).

It is also common to refer to project management and change management as distinct activities, which may provide support for the fourth position, where there is no need for direct positional authority or partnership between the roles. The roles may have separate reporting arrangements, with a project manager responsible to a program manager, and a change manager responsible to a designated change owner (Stummer \& Zuchi, 2010, p. 391 ), or through respective project and change management offices. The distinction between the two disciplines has resulted in a situation where "... project management and change management have been, and in most cases are, sold, practiced, and managed as two almost mutually exclusive project disciplines" (Jarocki, 2011, p. 69). In this case, the lack of relationship may be due to a clear, distinct, and commonly understood task differentiation.

Such clear task differentiation may be possible if the skills required to practice project management are different from those required to practice change management, and some authors have found this to be the case (e.g., Blake, 2009, p. 35; Baca, 2005; Alsene 1998, p. 373; Garfein \& Sankaran, 2011, p.1). However, research has also supported a contrary perspective, that there are similarities in the project manager and change manager roles (Crawford, 2011, p. 7). One interpretation is that the roles may be separated by the project stages that project managers and change managers work on. For example, Ainscough, Neailey, and Tennant (2003, p. 245) note that change management may help with practice 
Cite as: Pollack, J., Algeo, C. (2014) Perspectives on formal authority between Project Managers and Change Managers. Project Management Journal, 45(5), 27-43, DOI: 10.1002/pmj.21446.

deployment in assistance to project management, suggesting that change management may be used as an antecedent to project management.

Review of the literature does not reveal a significant body of knowledge about how these roles relate in practice. Where some insight is to be found, it is often only to be found through implication in what other authors have discussed, either through reference to the different stages to which project managers and change managers contribute, or an author's perspective on how the author's chosen field relates to another discipline. However, a perspective that gives preference to the familiar and local, and views the other as lesser or subservient, suggests academic imperialism of the sort that Reed (1985) describes, and so should be viewed with some caution. As such, it was considered significant to conduct a direct enquiry into practitioner perspectives of these roles, to understand how practitioners feel the disciplines should relate.

\section{Methodology}

The data for this research were collected using an online survey. Respondent anonymity was maintained. Three local industry association chapters assisted in survey distribution. A link to the survey was distributed through the researchers' professional networks and was also posted on the discussion boards of social media sites. This resulted in a convenience sample of 455 respondents. Data analysis was conducted using SPSS 19, statistical analysis software.

Although this is quantitative research, the authors have used an interpretivist perspective for analysis. This is in contrast to the positivist perspective, which is most commonly assumed when using quantitative techniques. Interpretivsm acknowledges that "....interpretation plays key, unacknowledged roles in how quantitative methods are actually employed" (Westerman, 2006, p. 189). An interpretivist perspective was considered appropriate as this is research into the perspectives of the respondents on project management and change management, and these perspectives will have been affected by a wide variety of diffuse factors, including their individual interpretation of questions, their experiences working in these fields, their mood at the time of response, and other factors that the researchers have no access to except through the survey questions asked. Interpretation of survey results has attempted to understand respondents' views of the relationships between these fields, while it acknowledges that the findings are providing, not a description of an objective reality, but a constructed account of survey answers for which alternative interpretations may also be valid.

The survey questions were developed in response to the literature review, starting with the assumption that there may be some conflict between practitioners of these disciplines, as other authors have identified. In response, two sets of questions were developed to help understand practitioners' perspectives about the relationship between project management and change management. First, it was considered important to understand the different organizational levels at which practitioners of these disciplines work. The first set of questions (Q1-2) related to participants views of the levels at which project managers and change managers should operate within an organization. These two questions treat project management and change management separately, allowing for independent classification. A full list of questions relevant to this research is provided in Appendix 1.

However, it was also considered important to elicit respondents' views of the relationship between the disciplines. If there was conflict related to disciplinary ownership of the management or organizational change projects, the authors considered that one area where this would manifest would be in terms of practitioners' views of the reporting relationships between the disciplines. The second set of questions (Q3-6) directly delved 
into this topic, asking respondents for their opinions about the kinds of reporting relationships that should exist between project management and change management, reflecting the four types of relationships identified in the literature review. Correlation between these six questions and a selection of other questions were investigated, and a list of the questions relevant to this research is included at the end of this paper. Where two variables were both ordinal, Spearman's Correlation was used; where two variables were nominal, or for the combination of a nominal with an ordinal variable, Fisher's Exact Test was used.

\section{Demographics}

The demographics of the respondents are as follows. The respondents were $66.2 \%$ male, with a median age of 45 years (9.2 year standard deviation). The majority $(82.9 \%)$ identified Australia as the country where they gained most of their experience. This is consistent with the collection method given the location of the participating industry associations, although there were another fifteen countries represented in the sample. The breakdown of industries is depicted in Figure 1 and can be seen to cover a broad crosssection of the industries in which these disciplines are practiced.

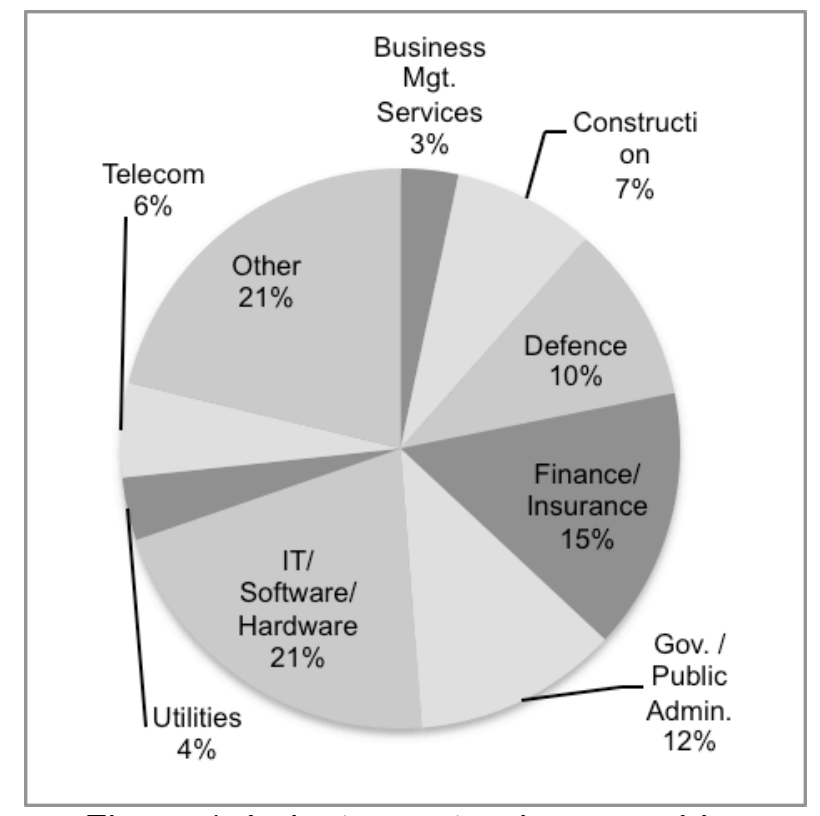

Figure 1: Industry sector demographics

Survey participants were asked: "How do you primarily professionally identify yourself?" and were given selection of the following options: "Project manager (including junior, senior, committee, and sponsor positions)"; change manager (including junior, senior, committee, and sponsor positions)"; or "other" with a free text field. Respondents identified themselves as follows: $56 \%$, project managers (256); $14 \%$, change managers (63); and $30 \%$, (136) "other" or an invalid response. "Other" and invalid respondents are excluded from the majority of analyses to focus more directly on the perceptions of project managers and change managers. The smaller number of change managers responding to the survey is considered consistent with the proportion of practicing change managers in Australia, compared to project managers. The survey respondents were asked "For how many years have you identified yourself in this way?" and their experience in these roles is listed in Table 1.

Given that there are many more project managers than change managers in the sample, the authors thought it important to account for respondents' knowledge of project management and change management when interpreting answers. Respondents were asked about their training and education, and for for project management, the most frequent 
response was that respondents had received "In-house or uncertified training" $(16.2 \%)$, followed by "Diploma" (15.5\%), and a "Master's degree (>50\% of project management subjects)" (14.6\%). With respect to change managemen training and education, the most frequent answer was "In-house or uncertified training" (39.0\%), followed by "No training" $(31.7 \%)$, and "Master's degree ( $<50 \%$ change management subjects)" $(7.9 \%)$.

\begin{tabular}{|c|c|c|c|}
\hline & \multicolumn{2}{|c|}{ How do you primarily professionally identify yourself? } \\
\hline & & Project Manager & Change Manager \\
\hline \multirow{9}{*}{$\begin{array}{l}\text { For how many } \\
\text { years have you } \\
\text { identified } \\
\text { yourself in this } \\
\text { way? }\end{array}$} & $0-5$ & $73(28.5 \%)$ & $36(57.1 \%)$ \\
\hline & $6-10$ & $78(30.5 \%)$ & $15(23.8 \%)$ \\
\hline & $11-15$ & $66(25.8 \%)$ & $7(11.1 \%)$ \\
\hline & $16-20$ & $22(8.6 \%)$ & $3(4.8 \%)$ \\
\hline & $21-25$ & $9(3.5 \%)$ & $0(0 \%)$ \\
\hline & $26-30$ & $4(1.6 \%)$ & $0(0 \%)$ \\
\hline & $31-35$ & $3(1.2 \%)$ & $2(3.2 \%)$ \\
\hline & $36-40$ & $1(0.4 \%)$ & $0(0 \%)$ \\
\hline & Total & $256(100 \%)$ & $63(100 \%)$ \\
\hline
\end{tabular}

Table 1: Respondents' years of experience

However, education and training provide only one perspective on respondents' knowledge, with many people undertaking personal study outside formal education and training. To account for this, respondents were asked about their familiarity with the factors identified below on a seven-point scale. An average was taken of the responses to each set of questions, and these were used to create two constructed variables, describing a respondent as having a low $(<=3)$, medium $(>3$ and $<5)$, or high $(>=5)$ knowledge of project management or change management.

Respondents' project management knowledge was based on their stated familiarity with:

- The role of a project manager;

- the PMBOK ${ }^{\circledR}$ Guide (PMI, 2008);

- PRINCE2 (OGC, 2009);

- Project Management Institute (PMI); and

- The Australian Institute of Project Management (AIPM).

Respondents' change management knowledge was based on their stated familiarity with:

- The role of a change manager;

- John Kotter's work (1996; and other work);

- Prosci and ADKAR; and

- The Change Management Institute (CMI).

Respondents' knowledge of project management and change management is depicted in Figure 2, as represented by these constructed variables. Respondents clearly considered that they were more knowledgeable about project management than change management, and this is consistent with the result above about the proportion of respondents with no education or training in change management. It is also consistent with how the respondents nominated their professional identification and should be considered when interpreting the results presented as follows.

\section{At What Level Should Project Managers Work?}

The first set of questions examines respondents' views of the organizational level at which project managers and change managers should operate. The first dependent variable was:

Q1: "In general, at what level of your organization should project management personnel mainly operate?" 


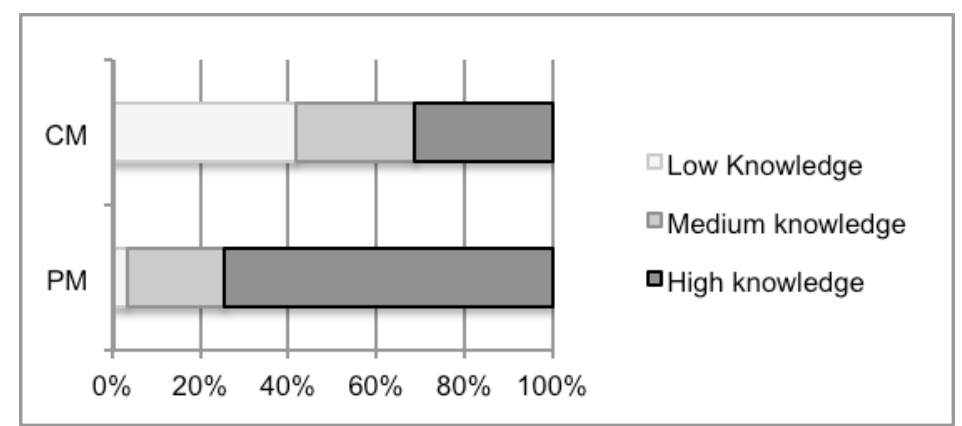

Figure 2: Respondents' knowledge of project management and change management

Most responded that project managers should work at an operational level, rather than at strategic or tactical levels. A correlation was detected using Fisher's Exact Test $(p<$ 0.05 ) between answers to Q1 and the questions: "Is the role of project manager a formal position title in the organization you currently work for?"; and "The position of project manager has clear roles and responsibilities in my organization." Cross-tabulated response frequencies are provided in Table 2. In these tables it is apparent that when the role of project manager was a formal position in the respondents' organization, and when project managers enjoyed clearly defined roles, respondents were particularly likely to regard project management as an operational activity.

\begin{tabular}{|c|c|c|c|c|c|c|}
\hline & & \multicolumn{5}{|c|}{$\begin{array}{l}\text { Question 1: In general at what } \\
\text { level of your organization } \\
\text { should project management } \\
\text { personnel mainly operate? }\end{array}$} \\
\hline & & 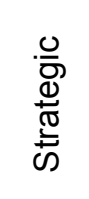 & 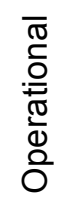 & 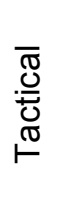 & 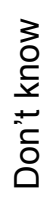 & $\begin{array}{l}\bar{\pi} \\
\stackrel{0}{0}\end{array}$ \\
\hline \multirow{7}{*}{$\begin{array}{l}\text { The position of } \\
\text { project manager has } \\
\text { clear roles and } \\
\text { responsibilities in my } \\
\text { organization }\end{array}$} & Completely Agree & 42 & 69 & 19 & 2 & 132 \\
\hline & Agree & 25 & 71 & 22 & 1 & 119 \\
\hline & Somewhat Agree & 9 & 28 & 10 & 1 & 48 \\
\hline & Neither Agree Or Disagree & 2 & 2 & 3 & 0 & 7 \\
\hline & Somewhat Agree & 6 & 5 & 4 & 1 & 16 \\
\hline & Disagree & 4 & 4 & 2 & 1 & 11 \\
\hline & Completely Disagree & 1 & 0 & 0 & 0 & 1 \\
\hline
\end{tabular}

\begin{tabular}{|l|l|c|c|c|c|c|}
\hline $\begin{array}{l}\text { Is the role of project } \\
\text { manager a formal } \\
\text { position title in the } \\
\text { organization you } \\
\text { currently work for? }\end{array}$ & Yes & 85 & 168 & 54 & 4 & 311 \\
\cline { 2 - 7 } & No & 5 & 13 & 6 & 1 & 25 \\
\cline { 2 - 7 } & Don't know & 0 & 0 & 0 & 1 & 1 \\
\hline
\end{tabular}

Table 2: Response frequencies for Question 1 and project management role clarity and position titles

Based on these correlations, it appears that the perception that project management should be used at an operational level of an organization is linked to acknowledgment within the organization and role clarity. It should be remembered that identification of a correlation does not indicate that one factor has caused a particular result; however, one interpretation is that an increase in the formalization and standardization of the role of project management in an organization has led to an increase in the consistency of responses. Of course, this 
Cite as: Pollack, J., Algeo, C. (2014) Perspectives on formal authority between Project Managers and Change Managers. Project Management Journal, 45(5), 27-43, DOI: 10.1002/pmj.21446.

interpretation assumes that the roles are consistent between organizations; an assumption that is neither confirmed nor denied by this research.

\section{At What Level Should Change Managers Work?}

Respondents were also asked about their view of the level at which change managers should operate. The second dependent variable was:

Q2: "In general, at what level of your organization should change management personnel mainly operate?"

It was possible to identify a correlation $(p<0.01)$ using Fisher's Exact Test between Q2 and the question: "How do you primarily professionally identify yourself?" Response frequencies are provided in Table 3.

\begin{tabular}{|l|l|c|c|}
\hline \multicolumn{2}{|c|}{} & \multicolumn{2}{c|}{$\begin{array}{c}\text { How do you primarily } \\
\text { professionally identify yourself? }\end{array}$} \\
\cline { 3 - 4 } \multicolumn{2}{|c|}{} & Project Manager & Change Manager \\
\hline $\begin{array}{l}\text { Question 2: In general, } \\
\text { at what level of your } \\
\text { organization should } \\
\text { change management } \\
\text { personnel mainly } \\
\text { operate? }\end{array}$ & Strategic & $105(42.5) \%$ & $39(61.9) \%$ \\
\cline { 2 - 4 } & Operational & $85(34.4) \%$ & 2133.3()$\%$ \\
\cline { 2 - 4 } & Tactical & $39(15.8) \%$ & $1(1.6) \%$ \\
\cline { 2 - 4 } & Don't know & $18(7.3) \%$ & $2(3.2) \%$ \\
\cline { 2 - 4 } & Total & $247(100) \%$ & $63(100) \%$ \\
\hline
\end{tabular}

Table 3: Response frequencies for Question 2 and occupation

From the results in Table 3 it is apparent that change management is generally regarded as a strategic activity. This result is strongest among those who identified themselves as change managers. This group showed a clear tendency to regard change management as an activity that should operate at the strategic levels of an organization, not the tactical levels.

Taking Q1 and Q2 together, the perception that project management should be at the operational levels of an organization and that change management should be at the strategic levels of an organization may at first glance suggest that project managers should report to change managers. However, the relationship between these disciplines became more complex on analyses of questions that specifically delve into practitioner perspectives of what this reporting relationship should be.

\section{Should Change Managers Report to Project Managers?}

If the responses to Q1 and Q2 suggest a position in which change managers are on a higher organizational level than project managers, it would be reasonable to assume that survey participants would also think that those in a higher organizational position should supervise the work of those at lower organizational levels.

This was examined through responses to Q3-6, each of which will be treated separately. To see whether this assumption could be rejected, respondents were asked about their agreement with the following statement on a seven-point scale.

Q3: "Change managers should report to project managers on all projects where change managers are required"

It would be reasonable to assume that participants would disagree with this statement, but this was not consistently the case. When responses to this question were categorized into three groups: "agree," "disagree," and "neither agree nor disagree" a 
correlation $(p<0.01)$ was apparent to responses to the question: "How do you primarily professionally identify yourself?" using Fisher's exact test (Table 4).

\begin{tabular}{|l|l|l|l|}
\hline \multirow{2}{*}{\multicolumn{2}{|c|}{}} & \multicolumn{2}{|c|}{$\begin{array}{c}\text { How do you primarily professionally } \\
\text { identify yourself? }\end{array}$} \\
\cline { 3 - 4 } \multicolumn{2}{|c|}{} & $\begin{array}{l}\text { Project manager } \\
\text { Change manager }\end{array}$ \\
\hline \multirow{2}{*}{$\begin{array}{l}\text { Question 3: Change managers } \\
\text { should report to project } \\
\text { managers on all projects where } \\
\text { change managers are required }\end{array}$} & Agree & $169(66.0) \%$ & $14(22.2) \%$ \\
\cline { 2 - 4 } & Neither & $37(14.5) \%$ & $10(15.9) \%$ \\
\cline { 2 - 4 } & Disagree & $50(19.5) \%$ & $39(61.9) \%$ \\
\cline { 2 - 4 } & Total & $256(100) \%$ & $63(100) \%$ \\
\hline
\end{tabular}

Table 4: Response frequencies for Question 3 and occupation

Survey respondents who identified themselves as a project manager were particularly likely to agree with the statement that change managers should report to project managers, whereas the change managers most frequently disagreed with the statement. If taken in isolation, and assuming that both of these disciplines are vying to assert a professional boundary around the management of organizational change, this finding would be uncontentious.

A weak correlation $(p<0.01$, coefficient $=0.166)$ was also apparent between responses to Q3 and respondents education and training in change management using Spearman's Correlation. Review of the cross-tabulated frequencies of responses to Q3 and respondents' education and training (Refer to Appendix 2) shows that lower levels of education or training in change management were correlated with a higher tendency to respond that change managers should report to project managers.

Similarly, a correlation $(p<0.01$, coefficient $=0.163$ ) was found between Q3 responses and respondents' knowledge of change management. Again, respondents who identified themselves as having a lower knowledge of change management, tended to state that change managers should report to project managers (Table 5). An implication of these two correlations is that people who are less aware of change management are more likely to assume it should take on a subservient role, and are less likely to understand the potential it holds in managing organizational change.

\begin{tabular}{|c|c|c|c|c|}
\hline & \multicolumn{3}{|c|}{ Project Management Knowledge } \\
\hline & & $\begin{array}{c}\text { Low } \\
\text { knowledge }\end{array}$ & $\begin{array}{c}\text { Medium } \\
\text { knowledge }\end{array}$ & $\begin{array}{c}\text { High } \\
\text { knowledge }\end{array}$ \\
\hline \multirow{8}{*}{ 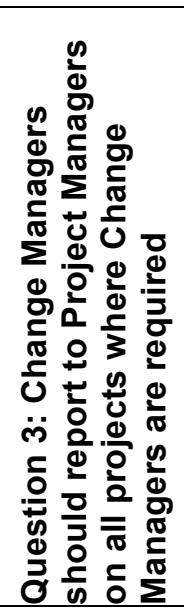 } & $\begin{array}{l}\text { Completely } \\
\text { Agree }\end{array}$ & 1 & 10 & 53 \\
\hline & Agree & 1 & 13 & 68 \\
\hline & $\begin{array}{l}\text { Somewhat } \\
\text { Agree }\end{array}$ & 2 & 10 & 34 \\
\hline & $\begin{array}{l}\text { Neither } \\
\text { Agree nor } \\
\text { Disagree }\end{array}$ & 1 & 11 & 39 \\
\hline & $\begin{array}{l}\text { Somewhat } \\
\text { Disagree }\end{array}$ & 0 & 9 & 15 \\
\hline & Disagree & 3 & 17 & 33 \\
\hline & $\begin{array}{l}\text { Completely } \\
\text { Disagree }\end{array}$ & 1 & 1 & 15 \\
\hline & Total & 9 & 71 & 257 \\
\hline
\end{tabular}

\begin{tabular}{|c|c|c|}
\hline \multicolumn{3}{|c|}{ Change Management Knowledge } \\
\hline $\begin{array}{c}\text { Low } \\
\text { knowledge }\end{array}$ & $\begin{array}{c}\text { Medium } \\
\text { knowledge }\end{array}$ & $\begin{array}{c}\text { High } \\
\text { knowledge }\end{array}$ \\
\hline 27 & 19 & 18 \\
\hline 39 & 28 & 15 \\
\hline 17 & 15 & 14 \\
\hline 29 & 10 & 12 \\
\hline 8 & 6 & 10 \\
\hline 14 & 13 & 26 \\
\hline 4 & 3 & 10 \\
\hline 138 & 94 & 105 \\
\hline
\end{tabular}

Table 5: Response frequencies for Question 3 and knowledge of the disciplines

Analysis revealed a weak correlation $(p<0.05$, coefficient $=-0.134)$ between answers to Q3 and respondents' project management knowledge using Spearman's Correlation (see Table 5). Respondents who identified themselves as having a greater knowledge of project 
management also tended to think that change managers should report to project managers. One interpretation of these results is that core texts in project management may encourage a view that change managers should report to project managers; however, this was not found in our review of the literature. An alternative interpretation is that this is more generally reflective of a project management tendency to regard the project manager as the central point of accountability and control in a project, and that people who had a higher knowledge of project management knowledge were stronger adherents to this perspective.

A selection of organizational indicators was also correlated with responses to Q3. There was a weak correlation $(p<0.05$, coefficient $=0.129)$ between $Q 3$ and the clarity of the role of project manager, using Spearman's Correlation (Refer to Appendix 3). Those working in organizations where project managers had clear roles and responsibilities showed a greater tendency to respond that change managers should report to project managers.

When responses to Q3 were categorized as variants of 'agree,' 'disagree,' or 'nether agree nor disagree,' the correlation $(p<0.05)$ could be seen with responses to: "Is the role of change manager a formal position title in the organization you currently work for?" using Fisher's Exact Test, and frequencies are cross-tabulated in Table 6 . When the role of change manager was not a formal position title in respondents' organizations, respondents were more likely to agree that change managers should report to project managers, and there was a greater tendency to disagree with the statement when the role of change manager was a formal position. This finding supports the suggestion above that when respondents' are unfamiliar with a role they are more likely to view it as subservient, of lesser managerial capability, or of less value than those with which they are more familiar.

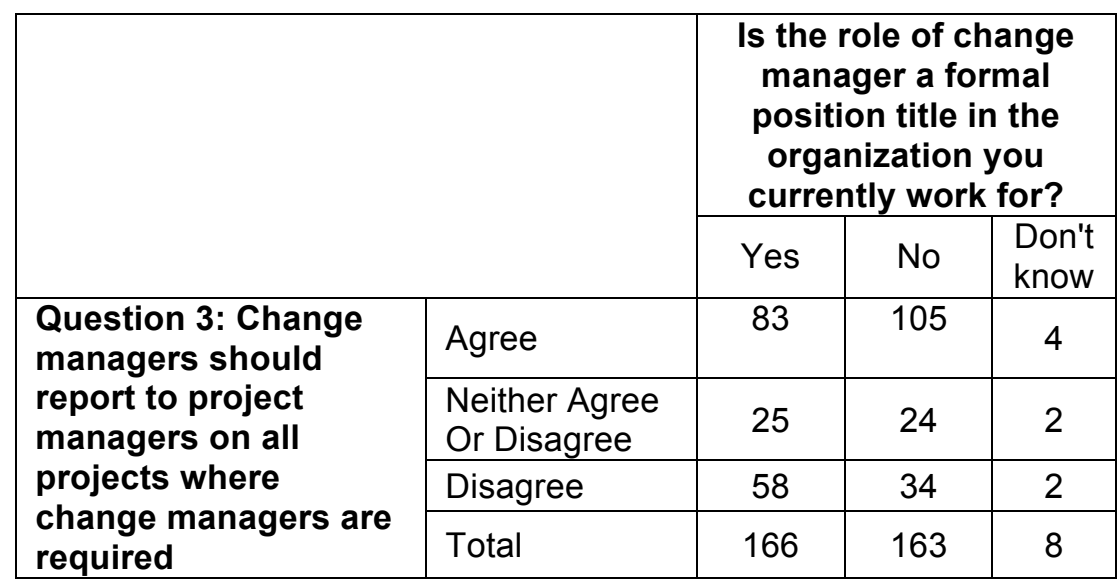

\begin{tabular}{|c|c|c|}
\hline \multicolumn{3}{|c|}{$\begin{array}{c}\text { Does your organization } \\
\text { have a unit focused on } \\
\text { developing change } \\
\text { management capability } \\
\text { (e.g., CMO or CCME) }\end{array}$} \\
\hline Yes & No & $\begin{array}{c}\text { Don't } \\
\text { know }\end{array}$ \\
\hline 53 & 128 & 11 \\
\hline 24 & 24 & 3 \\
\hline 40 & 53 & 1 \\
\hline 117 & 205 & 15 \\
\hline
\end{tabular}

Table 6: Response frequencies for Question 3, project manager as a formal position, and change management organizational support

Formalization of the role of change manager also appears to affect responses to Q3. Using Fisher's Exact Test, correlation $(p<0.01)$ was found between $Q 3$ and the presence of organizational structures supporting change management roles, and response frequencies are also provided in Table 6 . Respondents most frequently answered that change managers should report to project managers when their organization didn't have a group focused on developing change management capability; however, it is interesting to note that even in organizations that did have a unit focusing on change management capability, the most frequent response was still to agree that change managers should report to project managers. This can partly be attributed to the disproportionally large number of project managers responding to the survey.

One consistent finding is that lower levels of familiarity with change management, whether in terms of knowledge of key texts or supporting organizational structures, is correlated with the view that change managers should report to project managers. 
Cite as: Pollack, J., Algeo, C. (2014) Perspectives on formal authority between Project Managers and Change Managers. Project Management Journal, 45(5), 27-43, DOI: 10.1002/pmj.21446.

\section{Should Project Managers Report to Change Managers?}

In order to provide a balanced perspective on possible reporting relationships, respondents were also asked the opposite of the previous question. Respondents were asked about their agreement with the following statement on a seven-point scale.

Q4: "Project managers should report to change managers on all projects where change managers are required."

Correlation $(p<0.01)$ could be seen between answers to Q4 and respondents' answers to: "How do you primarily professionally identify yourself?" using Fisher's Exact Test (Table 7). Assuming an equally imperialist position between these disciplines, it would be reasonable to assume that the responses to Q3 would be the inverse of responses to Q4, and the project managers' responses to satisfy this assumption, consistently disagreeing with the prospect of reporting to a change manager. However, the results become more interesting when it is noted that the change managers have also predominantly disagreed with the possibility of project managers reporting to them.

\begin{tabular}{|l|l|c|c|c|}
\hline \multicolumn{2}{|c|}{} & \multicolumn{3}{|c|}{$\begin{array}{c}\text { How do you primarily } \\
\text { professionally identify } \\
\text { yourself? }\end{array}$} \\
\cline { 3 - 5 } & $\begin{array}{c}\text { Project } \\
\text { Manager }\end{array}$ & $\begin{array}{c}\text { Change } \\
\text { Manager }\end{array}$ & Total \\
\hline \multirow{2}{*}{$\begin{array}{l}\text { Question 4: } \\
\text { Project } \\
\text { managers } \\
\text { should report to } \\
\text { change } \\
\text { managers on all } \\
\text { projects where } \\
\text { project } \\
\text { managers are } \\
\text { required }\end{array}$} & Completely Agree & 2 & 5 & 7 \\
\cline { 2 - 5 } & Agree & 17 & 6 & 23 \\
\cline { 2 - 5 } & Somewhat Agree & 19 & 6 & 25 \\
\cline { 2 - 5 } & Neither Agree Or & 34 & 6 & 40 \\
\cline { 2 - 5 } & Sisagree & 25 & 9 & 34 \\
\cline { 2 - 5 } & Disagree & 87 & 23 & 110 \\
\cline { 2 - 5 } & Completely Disagree & 72 & 8 & 80 \\
\cline { 2 - 5 } & Total & 256 & 63 & 319 \\
\hline
\end{tabular}

\begin{tabular}{|c|c|c|c|}
\hline \multicolumn{4}{|c|}{$\begin{array}{c}\text { Project Management } \\
\text { Knowledge }\end{array}$} \\
\hline Low & Med. & High & Total \\
\hline 2 & 1 & 4 & 7 \\
\hline 0 & 7 & 17 & 24 \\
\hline 1 & 9 & 18 & 28 \\
\hline 0 & 7 & 34 & 41 \\
\hline 0 & 12 & 24 & 36 \\
\hline 6 & 21 & 93 & 120 \\
\hline 0 & 14 & 67 & 81 \\
\hline 9 & 71 & 257 & 337 \\
\hline
\end{tabular}

Table 7: Response frequencies for Question 4, occupation, and project management knowledge

Correlation $(p<0.05$, coefficient $=0.111)$ was also found between answers to Q4 and the respondents' project management knowledge, using Spearman's Correlation (Table 7). Respondents reporting a higher project management knowledge were more likely to disagree that project managers should report to change managers. There was also a correlation $(p<$ 0.01 ) between Q4 and respondents' primary industry sector (Refer to Appendix 4). Respondents from the IT/software/ hardware, finance/insurance, government/public administration, and telecommunications sectors were most likely to disagree with the idea of project managers reporting to change managers.

It is interesting to note that the only consistent tendency was for respondents to disagree with Q4. However, lack of agreement with this question raises an issue. If the change managers do not think that they should report to project managers or that project managers should be reporting to them, what do they think the reporting relationship between the change manager and project manager should be? Two more questions were asked, which will help clarify this issue. 
Cite as: Pollack, J., Algeo, C. (2014) Perspectives on formal authority between Project Managers and Change Managers. Project Management Journal, 45(5), 27-43, DOI: 10.1002/pmj.21446.

\section{Should Change Managers and Project Managers Act Independently?}

An alternative to one discipline reporting to the other would be for the two disciplines to act independently. Respondents were asked about their agreement with the following statement on a seven-point scale.

Q5: "Change management and project management are independent roles and responsible for separate scopes of work. There is no need for direct reporting between these roles."

There were no apparent correlations between respondents' answers to Q5 and responses to other questions; although a tendency could be seen for respondents to generally disagree that the two roles were entirely separate.

\section{Should Change Managers and Project Managers Act Jointly?}

The final reporting relationship considered was for an independent reporting relationship, but joint responsibility. Respondents were asked about their agreement with the following statement on a seven-point scale:

Q6: "Change and project management personnel should work together in partnership with joint responsibility for project success. There is no need for direct reporting between these roles."

It is here that the change managers' perspective on the reporting relationship starts to become clearer. Using Fisher's Exact Test, Correlation $(p<0.05)$ was apparent between responses to Q6 and responses to: "How do you primarily professionally identify yourself" (Table 8). Respondents who identified themselves as a change manager were significantly more likely to agree with this statement.

\begin{tabular}{|l|l|c|c|}
\hline \multirow{2}{*}{\multicolumn{2}{|c|}{}} & \multicolumn{2}{c|}{$\begin{array}{c}\text { How do you primarily } \\
\text { professionally identify yourself? }\end{array}$} \\
\cline { 3 - 4 } & Project Manager & Change Manager \\
\hline \multirow{2}{*}{$\begin{array}{l}\text { Question 6: Change and } \\
\text { project management } \\
\text { personnel should work } \\
\text { together in partnership } \\
\text { with joint responsibility } \\
\text { for project success. }\end{array}$} & Completely Agree & $50(19.5) \%$ & $25(39.7) \%$ \\
\cline { 2 - 4 } $\begin{array}{l}\text { There is no need for } \\
\text { direct reporting between } \\
\text { these roles }\end{array}$ & Agree & $72(28.1) \%$ & $18(28.6) \%$ \\
\cline { 2 - 4 } & Somewhat Agree & $40(15.6) \%$ & $10(15.9) \%$ \\
\cline { 2 - 4 } & Neither Agree nor Disagree & $24(9.4) \%$ & $1(1.6) \%$ \\
\cline { 2 - 4 } & Somewhat Disagree & $15(5.9) \%$ & $3(4.8) \%$ \\
\cline { 2 - 4 } & Completely Disagree & $33(12.9) \%$ & $4(6.3) \%$ \\
\cline { 2 - 4 } & Total & $22(8.6) \%$ & $2(3.2) \%$ \\
\hline
\end{tabular}

Table 8: Response frequencies for Question 6 and occupation

\section{Discussion}

When the response frequencies for Q3-6 are reviewed (Figure 3), it can be seen that when taken as a whole the respondents tended to agree with change managers reporting to project managers and with joint responsibility but separate reporting relationships. More specifically, the project managers tended to answer that change managers should report to project managers, and the change managers typically answered in favor of joint responsibility for delivery.

The responses provided by the survey participants also appear to have been contingent upon a number of factors. Identifying the role with a formal position title and clearly defined roles and responsibilities within an organization were generally associated with the perception that one discipline should have managerial responsibility over the other discipline, whereas a lack of these factors was associated with a perception of subservience. 
Cite as: Pollack, J., Algeo, C. (2014) Perspectives on formal authority between Project Managers and Change Managers. Project Management Journal, 45(5), 27-43, DOI: 10.1002/pmj.21446.

Formalization of the position appears to raise its perceived status within an organization. In addition, respondents' education, knowledge of a discipline, and professional orientation were also factors that were frequently correlated with respondents' perceptions of a discipline's status. In particular, a lack of familiarity with a discipline was found to be associated with the assumption that the discipline should be of a lower status. The way these disciplines were perceived was found to not only be contingent upon the organizational setting, but also the way in which practitioners have been shaped by their education, training, and professional affiliation.

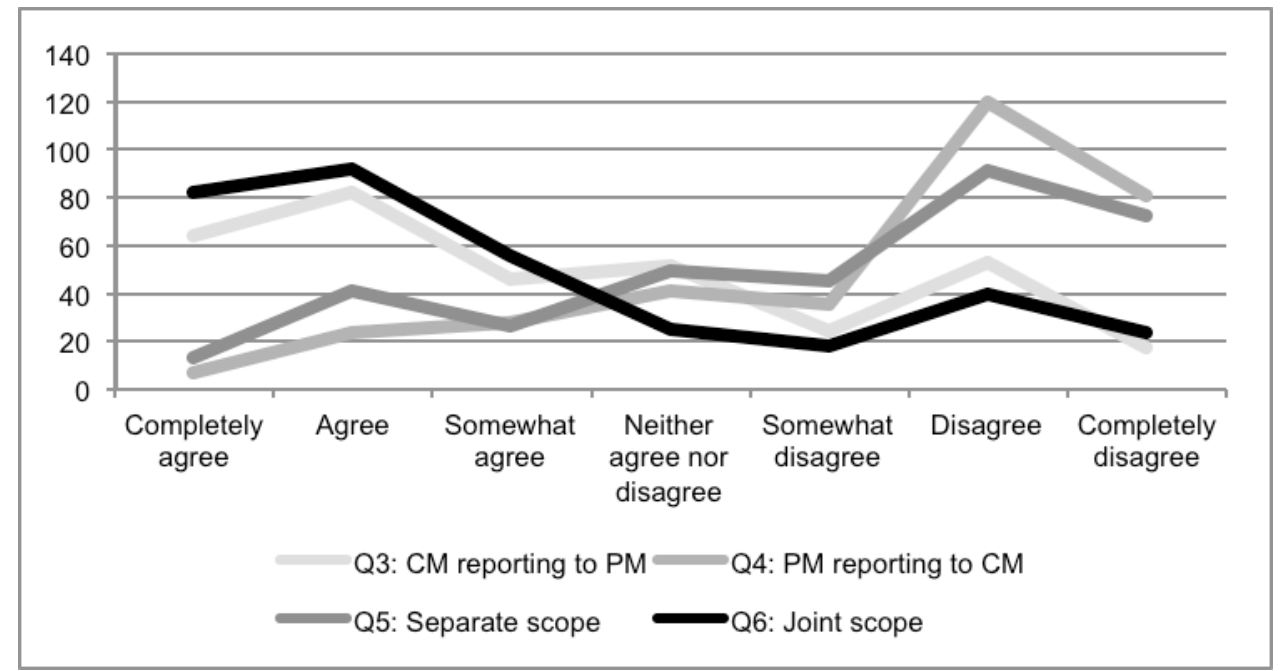

Figure 3: Frequencies of responses to Questions 3 through 6

The different opinions on reporting relationships between respondents who identified themselves as project managers or change managers suggests a difference in perspective that is significantly more complex than can be accounted for by a basic imperialist perspective on the relationship between disciplines. Abbott (1988) considers that the move toward acknowledgment of a discipline's professional boundary needs to be understood in terms of the "...complex facts of jurisdictional competition and inter-professional relationships" (Abbott, 1988, p. 23). The process of claiming "...control of work in the workplace, before the public, and within the state [is] ... determined by the ensemble of this melee of interaction" (Abbott, 2001, p. 12168); a melee that may become more complex if the different disciplines vying for control of an area of work are not sharing a common meaning.

The differences between project management and change management hint at disagreement not only about the discipline that should be accountable for managing change, but also about how changes to organizations should be managed. This is not surprising, given that although some parts of the literature may be converging, the early development of these disciplines was grounded in distinct literatures. Fundamental concepts within the discipline of project management include unambiguous definition of single points of accountability for activities within a work breakdown structure. Despite many project managers working in environments typified by diffuse networks of influence and decision making, it is typically taken for granted that the project manager will assume responsibility for the success or failure of the project. When the roles of project manager and change manager are contrasted, a greater tendency for project managers to use a control agenda has been identified (Crawford, 2011, p. 4), whereas a strong focus on structure is also apparent within key texts in the field (e.g. PMI, 2013b; OGC, 2009). Project management research has also suggested that successful management of organizational change projects is associated with "...specific lines of authority linking the senior team to the operational team" (Boddy \& Macbeth, 2000, p. 300). 
Cite as: Pollack, J., Algeo, C. (2014) Perspectives on formal authority between Project Managers and Change Managers. Project Management Journal, 45(5), 27-43, DOI: 10.1002/pmj.21446.

In comparison, the literature on change management places a much greater focus on organizational and individual empowerment, including even those aspects of the change management literature that focus on leader-led change. The delivery of organizational changes is regarded as a collective activity. Change managers may play a role in facilitating and encouraging other people to change, as opposed to controlling the way that changes take shape. When contrasting project management and change management, Blake (2009, p. 35) has noted the purpose of project management as the achievement of goals within the constraints of time, cost, and quality, whereas the purpose of change management is to "...manage the people-side of business change to achieve the most successful business outcome." These differences suggest that project managers and change managers do not see their managerial roles in equivalent ways. Discussing the reporting relationship between a project manager and a change manager assigned to deliver a single organizational change may then become problematic.

It is also worth noting that the data analysis did not reveal a correlation between respondents' who were categorized as having a high level of knowledge of change management with other questions. One interpretation is that this may be attributed to the change management literature, which is diffuse compared with the project management literature, with writers contributing to change management research from a broad range of disciplinary backgrounds. Al-Sediary (2011, p. 163) has identified that with respect to the change managemen literature there "... is surprisingly little consensus with regard to its definition and boundaries." There are no commonly agreed-on dominant guides to change management, and when compared with project management, specialist industry associations are only a recent development. These factors may have resulted in lower levels of consistency in the answers provided by people who were categorized as having a higher knowledge of change management. However, this result should be contracted with the finding that correlation was found between respondents' tendency to identify themselves as a change manager and the results of many other questions. This suggests that, although the boundaries of change management may as yet be less defined than those of project management, there are core aspects of the change manager, which are consistently agreed upon among change managers.

Upon review of the six questions on which this paper focuses, it is possible to see a tension between the answers respondents provided to the first set of questions (Q1-2) and the second set (Q3-6). In Figure 4 it can be seen that respondents most frequently perceived change management as strategic and project management as operational, suggesting that change management should be at a higher level of an organization than project management, in which case it would be unusual for a change manager to report to a project manager. However, respondents' answers to the second set of questions provided a contrasting picture. The project managers tended to answer that they should supervise change managers' work, and the change managers tended to view the relationship as one of joint responsibility without a defined reporting relationship.

The conflict between these seemingly contradictory groups of responses can be resolved through reflection on respondents' possible interpretations of the first set of questions. Q1 and Q2 were intended to elicit responses that reflected respondents' perspectives on the levels of their organization in which the disciplines should work, using the terms 'strategic,' 'operational,' and 'tactical.' It is possible, however, that these terms have been taken as descriptors of the type of activity involved in project management and change management, rather than indicating a position in an organizational hierarchy. This interpretation is broadly consistent with the authors' views of these disciplines, with project management focusing on functionalist operational-type issues, including scheduling, managing a budget, change control, and procurement, whereas change management focuses on strategic-type activities, such as empowering change agents, developing a senior guiding coalition, ensuring their support, and removing organizational obstacles. 
Cite as: Pollack, J., Algeo, C. (2014) Perspectives on formal authority between Project Managers and Change Managers. Project Management Journal, 45(5), 27-43, DOI: 10.1002/pmj.21446.

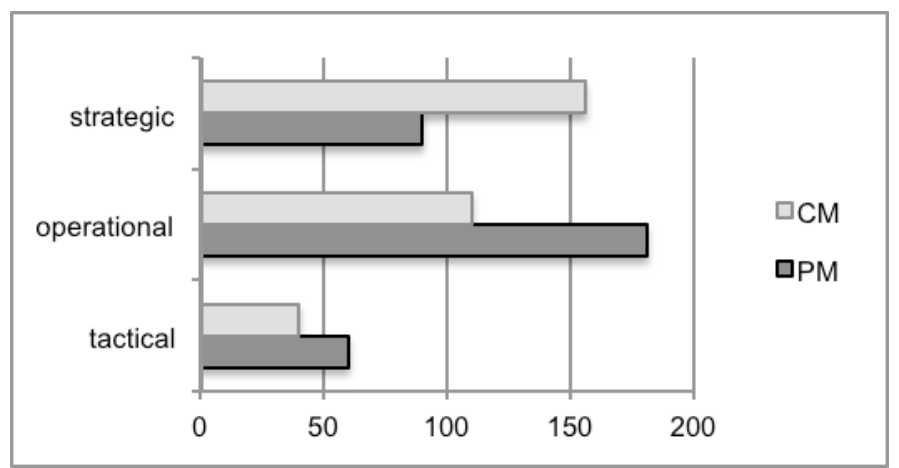

Figure 4: Strategic, operational, and tactical-type activities

The results of this research suggest that change managers may encounter difficulties in organizational settings and with project managers, where there is a common assumption that they should operate in a broader project management mandate. In such cultures, the way forward may be to focus on formalizing the role of the change manager, and focus on developing awareness of what change management is, and the benefits that it could provide within an organization. The publication of PMI (2013a) can be considered to be a step toward developing a broader awareness of change management in the project management community. However, the authors suggest that this work should be revisited with a view toward examining the role of the change manager, rather than treating change management as a disembodied skillset, enacted by unspecified individuals. For project managers, the implications of this research suggest a need to find some balance between the need for control and direction that comes with a single point of accountability, and allowing change managers to have a distinct area of responsibility that they can deliver in their own way, while maintaining coordination between the project management and change management aspects of organizational change projects.

\section{Conclusion}

To identify whether project managers and change managers hold different views about how these two roles should formally relate in practice, and then understand whether this could contribute to any conflict between the disciplines, this research has studied the different ways in which practitioners holding these roles view possible reporting relationships between project management and change management. The responses show that although the project managers thought that change managers should be reporting to them, the change managers saw the relationship as one of joint responsibility without a direct reporting relationship. The contrast between these perspectives hints at broader differences in the worldviews through which practitioners of these disciplines interpret the world, suggesting much larger differences in opinion about how organizational change projects should be managed, and differences in the ways in which fundamental questions of management and engagement are understood, including what success is and the ways in which it should be achieved. These issues extend beyond the scope of this research.

An association was also apparent between the view that change managers should report to project managers and lower levels of formalization and organizational support for change management, and lower levels of knowledge, education, and training in change management. These results suggest that change managers who are facing enduring conflict about reporting relationships should focus on increasing organizational understanding about change management, and developing structures within their organizations that support change management, such as a Center of Excellence or a change management office. It is unclear from these results whether the same would be true for project managers faced with these difficulties. These findings also suggest that for project managers who are sharing the 
Cite as: Pollack, J., Algeo, C. (2014) Perspectives on formal authority between Project Managers and Change Managers. Project Management Journal, 45(5), 27-43, DOI: 10.1002/pmj.21446.

delivery of organizational change projects with change managers, there will be a need to maintain a careful balance between the need for central coordination and control, while allowing change managers the space and autonomy to deliver their remit.

Project management was also found to be viewed primarily as an operational activity, whereas change management was generally regarded as a strategic activity. Review of the data suggests that this represents less an indicator of the relative levels of an organization at which these disciplines should work, than a description of the kinds of roles that these disciplines play in delivering organizational changes. The exact nature of these activities, or the stages of an organizational change that project managers and change managers should and do engage with, remains a topic for future research.

\section{References}

Abbott, A. (1988). The system of professions. Chicago, IL: University of Chicago Press.

Abbott, A. (2001). Sociology of professions, in Smelser, N. \& Baltes, P. (Eds.), International Encyclopaedia of the Social and Behavioral Sciences, Pergamon, pp. 12166-12169.

Ainscough, M., Neailey, K., \& Tennant, C. (2003). A self-assessment tool for implementing concurrent engineering through change management. International Journal of Project Management, 21, 425-431.

Al-Sedairy, S.T. (2001). A change management model for Saudi construction industry. International Journal of Project Management, 19, 161-169.

Alsene, E. (1998). Internal changes and project management structures within enterprises. International Journal of Project Management, 17, 367-376.

Baca, C. (2005). Project manager's spotlight on change management. San Francisco, CA: Harbor Light Press.

Blake, I. (2009). Project managing change: Practical tools and techniques to make change happen. New York, NY: Financial Times/Prentice Hall.

Boddy, D., \& Macbeth, D. (2000). Prescriptions for managing change: A survey of their effects in projects to implement collaborative working between organisations. International Journal of Project Management, 18, 297-306.

Cao, G., \& McHugh, M. (2005). A systemic view of change management and its conceptual underpinnings. Systemic Practice and Action Research, 18, 475-490.

Change Management Institute (CMI). (2012). Change management practitioner competencies. Retrieved from http://www.change-managementinstitute.com/sites/default/files/cmi_accreditation_cmpcompetencymodel.pdf;

Clarke, A. (1999). A practical use of key success factors to improve the effectiveness of project management. International Journal of Project Management, 17, 139-145.

Connor, D. (1993). Managing at the speed of change. New York, NY: Random House.

Cowan-Sahadath, K. (2010). Business transformation: Leadership, integration and innovation: A case study. International Journal of Project Management, 28, 395-404.

Crawford, L. (2011). Adding change implementation to the project manager's toolkit. In Proceedings of the Annual Project Management Australia Conference (PMOz): Project Management at the Speed of Light, Sydney, NSW, 2-5 August, 2011.

Crawford, L., \& Nahmais, A. (2010). Competencies for managing change. International Journal of Project Management, 28, 405-412.

Dover, P. A. (2002). Change agents at work: Lessons from Siemens Nixdorf. Journal of Change Management, 3, 243-257.

Fiedler, S. (2010). Managing resistance in an organizational transformation: A case study from a mobile operator company. International Journal of Project Management, 28, 370-383.

Gareis, R. (2010). Changes of organizations by projects. International Journal of Project Management, 28, 314-327.

Garfein, S. J., \& Sankaran, S. (2011). Work preferences of project and program managers, change managers and project team members: The importance of knowing the difference. In PMI Global Congress, Dallas, Texas, 22-25 October, 2011.

Griffith-Cooper, B., \& King, K. (2007). The partnership between project management and organizational change, Performance Improvement, 46, 14-20.

Jarocki, T.L. (2011). The next evolution: Enhancing and unifying project and change management. San Francisco, CA: Brown and Williams. 
Cite as: Pollack, J., Algeo, C. (2014) Perspectives on formal authority between Project Managers and Change Managers. Project Management Journal, 45(5), 27-43, DOI: 10.1002/pmj.21446.

Kloppenborg, T., \& Opfer, W. (2002). The current state of project management: Trends, interpretations, and predictions. Project Management Journal, 33(2), 5-18.

Kotter, J. (1996). Leading change. Boston, MA: Harvard Business School Press.

Kwak, Y., \& Anbari, F. (2009). Analyzing project management research: Perspectives from top management journals. International Journal of Project Management, 27, 435-446.

Lehmann, V. (2010). Connecting changes to projects using a historical perspective: Towards some new canvases for researchers. International Journal of Project Management, 28, 328-338.

Leppitt, N. (2006). Challenging the code of change: Part 2. Crossing the Rubicon: Extending the integration of change. Journal of Change Management, 6(3), 235-256.

Levasseur, R. (2010). People skills: Ensuring project success - A Change Management Perspective. Interfaces, 40(2), 159-162.

Leybourne, S. (2006). Improvisation within the project management of change: Some observations from UK financial services. Journal of Change Management, 6(4), 365-381.

Leybourne, S. (2007). The changing bias of project management research: A consideration of the literatures and an application of extant theory. Project Management Journal, 38(1), 61-73.

Mento, A., Jones, R., \& Dirndorfer, W. (2002). A change management process: Grounded in both theory and practice. Journal of Change Management, 3(1), 45-59.

Morris, P. (2002). Science, objective knowledge, and the theory of project management. Proceedings of the ICE - Civil Engineering, 150(2), 82-90.

Morris, P. (2013). Reconstructing project management reprised: A knowledge perspective. Project Management Journal, 44(5), 6-23.

Nelson, K. (2011). Change management: Understanding the human dynamics of change. PMI Global Congress Proceedings, Dallas, Texas.

Office of Government Commerce. (OGC). (2009). Managing successful projects with PRINCE2. London, UK: The Stationary Office.

Pádár, K., Pataki, B., \& Sebestyen, Z. (2011). A comparative analysis of stakeholder and role theories in project management and change management. International Journal of Management Cases, 14, 252-260.

Phillips, J. (1983). Enhancing the effectiveness of organizational change management. Human Resource Management, 22(1-2), 183-199.

Project Management Institute. (PMI). (2013a). Managing change in organizations: A practice guide. Newtown Square, PA: Author.

Project Management Institute. (PMI). (2013b). A guide to the project management body of knowledge (PMBOK ${ }^{\circledR}$ guide) - Fifth edition. Newtown Square, PA: Author.

Reed, M. (1985). Redirections in organizational analysis. London, UK: Tavistock.

Söderlund, J. (2004). On the broadening scope of the research on projects: A review and a model for analysis. International Journal of Project Management, 22, 655-667.

Stummer, M., \& Zuchi, D. (2010). Developing roles in change processes:A case study from a public sector organisation. International Journal of Project Management, 28, 384-394.

Turner, J.R., Grude, K.V., \& Thurloway, L. (1996). The project manager as change agent : leadership, influence and negotiation. New York, NY: McGraw-Hill.

Urli, B., \& Urli, D. (2000). Project management in North America: Stability of the concepts. Project Management Journal, 31, 33-43.

Westerman, M. (2006). Qualitative research as an interpretive enterprise: The mostly unacknowledged role of interpretation in research efforts and suggestions for explicitly interpretive quantitative investigations. New Ideas in Psychology, 24, 189-211.

Winch, G., Meunier, M., Head, J., \& Russ, K. (2012). Projects as the content and process of change: The case of the health safety laboratory. International Journal of Project Management, 20, $141-152$.

Yeo, K.T. (1993). Systems thinking and project management: Time to reunite. International Journal of Project Management, 11, 111-117. 
Cite as: Pollack, J., Algeo, C. (2014) Perspectives on formal authority between Project Managers and Change Managers. Project Management Journal, 45(5), 27-43, DOI: 10.1002/pmj.21446.

\section{Appendix 1:The survey questions referred to in this paper}

Primary questions

- Q1: In general at what level of your organization should project management personnel mainly operate?

- Q2: In general at what level of your organization should change management personnel mainly operate?

In general, how much you agree with the following statements?

- Q3: Change managers should report to project managers on all projects where change managers are required

- Q4: Project managers should report to change managers on all projects where change managers are required

- Q5: Change management and project management are independent roles and responsible for separate scopes of work. There is no need for direct reporting between these roles

- Q6: Change and project management personnel should work together in partnership with joint responsibility for project success. There is no need for direct reporting between these roles

Ancillary questions

- In which industry did you primarily gain your experience?

- How do you primarily professionally identify yourself?

- For how many years have you identified yourself in this way?

- What is your highest level of project management training or qualification?

- What is your highest level of change management training or qualification?

- How familiar are you with the role of a project manager?

- How familiar are you with the PMBOK ${ }^{\circledR}$ Guide (PMI, 2008)?

- How familiar are you with PRINCE2 (OGC, 2002)?

- How familiar are you with the Project Management Institute (PMI)?

- How familiar are you with the Australian Institute of Project Management (AIPM)?

- How familiar are you with the role of a change manager?

- How familiar are you with John Kotter's work (Leading Change and other works)?

- How familiar are you with Prosci and ADKAR (http://www.prosci.com)?

- How familiar are you with the Change Management Institute?

- Is the role of project manager a formal position title in the organization you currently work for?

- The position of project manager has clear roles and responsibilities in my organization

- Is the role of change manager a formal position title in the organization you currently work for?

- Does your organization have a unit focused on developing change management capability (e.g., CMO or CCME)? 


\section{Appendix 2: Response frequencies for Question 3 and change management training}

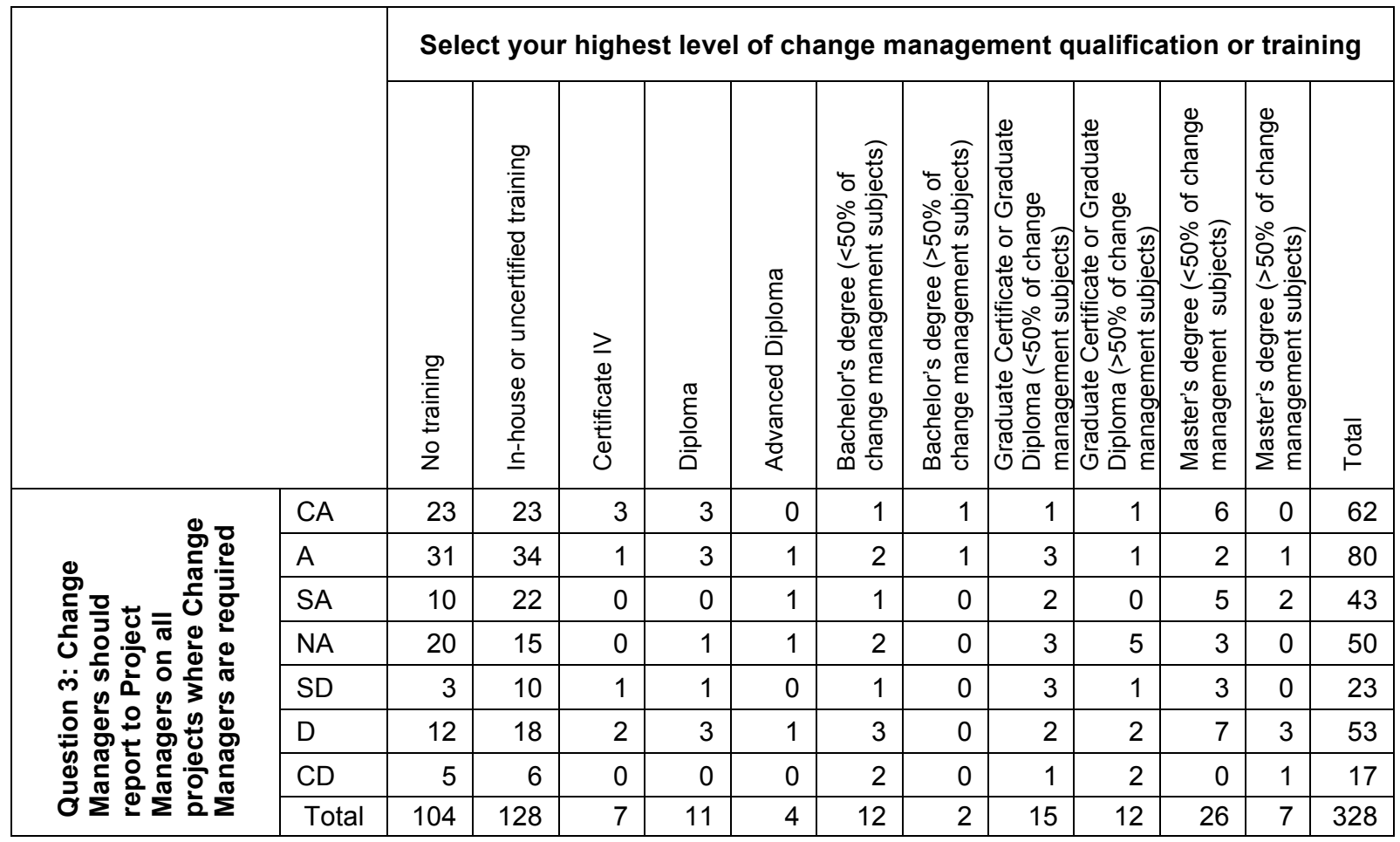

Appendix 3: Response frequencies for Question 3 and project manager role clarity

\begin{tabular}{|c|c|c|c|c|c|c|c|c|c|}
\hline & \multicolumn{8}{|c|}{$\begin{array}{l}\text { The position of project manager has clear roles and } \\
\text { responsibilities in my organization }\end{array}$} \\
\hline & & CA & A & SA & NA & SD & D & $C D$ & Total \\
\hline \multirow{8}{*}{ 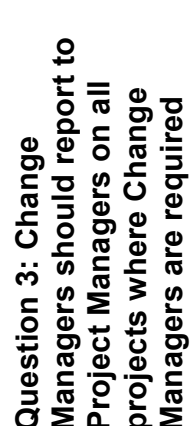 } & $C A$ & 37 & 16 & 7 & 1 & 0 & 1 & 1 & 63 \\
\hline & $A$ & 30 & 35 & 11 & 0 & 4 & 2 & 0 & 82 \\
\hline & SA & 13 & 14 & 4 & 3 & 6 & 4 & 0 & 44 \\
\hline & NA & 20 & 20 & 6 & 2 & 1 & 2 & 0 & 51 \\
\hline & SD & 8 & 4 & 7 & 1 & 3 & 1 & 0 & 24 \\
\hline & $D$ & 18 & 22 & 11 & 0 & 1 & 1 & 0 & 53 \\
\hline & $C D$ & 6 & 8 & 2 & 0 & 1 & 0 & 0 & 17 \\
\hline & $\begin{array}{c}\text { Tot } \\
\text { al }\end{array}$ & 132 & 119 & 48 & 7 & 16 & 11 & 1 & 334 \\
\hline
\end{tabular}


Cite as: Pollack, J., Algeo, C. (2014) Perspectives on formal authority between Project Managers and Change Managers. Project Management Journal, 45(5), 27-43, DOI: 10.1002/pmj.21446.

Appendix 4: Response frequencies for Question 4 and industry sector

\begin{tabular}{|c|c|c|c|c|c|c|c|c|c|}
\hline & 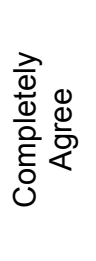 & ఖ & 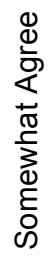 & 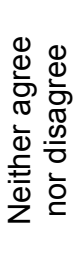 & 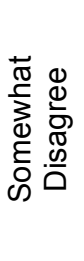 & 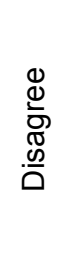 & 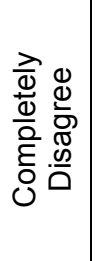 & $\stackrel{\bar{\pi}}{0}$ \\
\hline & & \multicolumn{8}{|c|}{$\begin{array}{l}\text { Question 4: Project managers should report to } \\
\text { change managers on all projects where project } \\
\text { managers are required }\end{array}$} \\
\hline \multirow{6}{*}{ 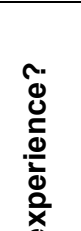 } & Aerospace & 0 & 0 & 0 & 0 & 0 & 3 & 1 & 4 \\
\hline & Agriculture/Forestry & 1 & 0 & 0 & 0 & 0 & 0 & 0 & 1 \\
\hline & Architecture/Design & 0 & 0 & 1 & 1 & 0 & 0 & 2 & 4 \\
\hline & Business Management Services & 0 & 0 & 1 & 1 & 2 & 4 & 2 & 11 \\
\hline & Coal/Gas/Oil & 0 & 2 & 0 & 0 & 1 & 3 & 1 & 7 \\
\hline & Construction: commercial/ industrial & 0 & 5 & 3 & 6 & 2 & 3 & 5 & 24 \\
\hline \multirow{4}{*}{ 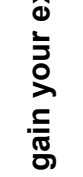 } & Construction: land development & 0 & 0 & 0 & 0 & 1 & 0 & 0 & 1 \\
\hline & $\begin{array}{l}\text { Construction: infrastructure } \\
\text { development }\end{array}$ & 0 & 0 & 1 & 1 & 0 & 0 & 0 & 2 \\
\hline & Culture/Arts & 0 & 0 & 1 & 0 & 0 & 1 & 0 & 2 \\
\hline & Defence & 2 & 2 & 3 & 7 & 3 & 9 & 8 & 34 \\
\hline \multirow{7}{*}{ 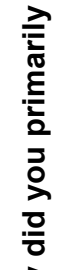 } & Education/Training & 0 & 0 & 0 & 0 & 4 & 0 & 0 & 4 \\
\hline & Finance/Insurance & 1 & 2 & 3 & 4 & 6 & 20 & 14 & 50 \\
\hline & Government/Public Administration & 1 & 3 & 1 & 5 & 2 & 15 & 12 & 39 \\
\hline & Health/Social Services & 0 & 2 & 1 & 0 & 0 & 3 & 1 & 7 \\
\hline & IT/Software/Hardware & 1 & 4 & 4 & 6 & 8 & 27 & 19 & 69 \\
\hline & Legal & 0 & 0 & 0 & 0 & 0 & 1 & 0 & 1 \\
\hline & Manufacturing & 0 & 0 & 1 & 1 & 0 & 2 & 2 & 6 \\
\hline \multirow{8}{*}{ 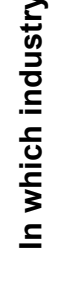 } & Mining & 0 & 0 & 0 & 1 & 1 & 0 & 2 & 4 \\
\hline & Pharmaceutical & 0 & 0 & 0 & 0 & 0 & 1 & 0 & 1 \\
\hline & Telecommunications & 0 & 0 & 1 & 2 & 1 & 10 & 4 & 18 \\
\hline & Tourism & 0 & 0 & 1 & 1 & 0 & 0 & 0 & 2 \\
\hline & Transport & 0 & 0 & 0 & 2 & 1 & 3 & 1 & 7 \\
\hline & Utilities & 0 & 1 & 2 & 2 & 0 & 3 & 4 & 12 \\
\hline & Other & 0 & 1 & 2 & 1 & 3 & 7 & 2 & 16 \\
\hline & Total & 7 & 22 & 26 & 41 & 35 & 115 & 80 & 326 \\
\hline
\end{tabular}

